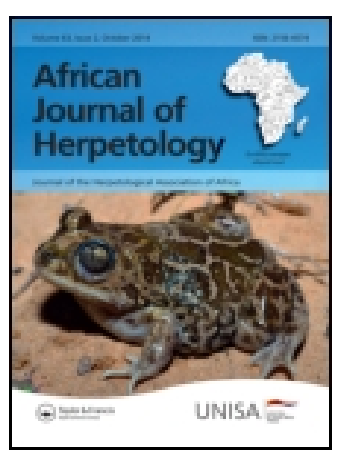

African Journal of Herpetology

ISSN: 2156-4574 (Print) 2153-3660 (Online) Journal homepage: http://www.tandfonline.com/loi/ther20

\title{
Annual variation of ovarian structures of Boulengerula taitana (Loveridge 1935), a Kenyan caecilian
}

\section{A. Raquet, G. J. Measey \& J. M. Exbrayat}

To cite this article: M. A. Raquet, G. J. Measey \&J. M. Exbrayat (2015) Annual variation of ovarian structures of Boulengerula taitana (Loveridge 1935), a Kenyan caecilian, African Journal of Herpetology, 64:2, 116-134, DOI: 10.1080/21564574.2015.1103787

To link to this article: http://dx.doi.org/10.1080/21564574.2015.1103787

曲 Published online: 13 Nov 2015.

Submit your article to this journal $₫$

Џll Article views: 8

Q View related articles $₫$

View Crossmark data $\nearrow$ 


\title{
Annual variation of ovarian structures of Boulengerula taitana (Loveridge 1935), a Kenyan caecilian
}

\author{
M. A. Raquet ${ }^{1 *}$, G. J. Measey ${ }^{2} \&$ J. M. Exbrayat ${ }^{1}$ \\ ${ }^{1}$ Université de Lyon, UMRS 449, Laboratoire de Biologie générale, UCLy, Reproduction et développement \\ comparé, EPHE, 25 rue du Plat, F-69288 Lyon cedex, France; ${ }^{2}$ Centre for Invasion Biology, Department of \\ Botany \& Zoology, Stellenbosch University, Stellenbosch, South Africa
}

\begin{abstract}
The Kenyan caecilian, Boulengerula taitanus inhabits a climate characterised by two distinct dry and wet seasons, and a single thermal minimum in June. It is oviparous with direct development and a remarkable dermatophagous maternal care, but the female reproductive cycle until now remains unknown. The purpose of this work was to complete the knowledge about the reproductive modes of this species, using anatomical and histological studies of the ovaries. Quantitative variations of follicle categories showed a continuous folliculogenesis. Yet, young corpora lutea were only detected between November and February during the short rain season and the short dry season, indicating ovulation occurred during these four months during the thermal maximum. Oestrogen and progesterone detection allowed determination of three reproductive periods during the year: preparation in September and October, ovulation from November until February and quiescence from March until August. So, the female reproductive cycle of $B$. taitanus appears to be annual and synchronised with testicular evolution. Because the ovulation was observed following the second peak of follicle production (beginning of June), temperature is supposed to be the main regulating factor of reproductive pattern in this caecilian.
\end{abstract}

Key words.-Amphibians, Boulengerula taitana, caecilians, immunohistochemistry amphibians, Gymnophiona, oogenesis, reproduction hormones, seasonality.

\section{INTRODUCTION}

Anuran and urodelan reproductive cycles have been well studied, mostly in northern temperate latitudes where they are strongly linked to seasonal variations, especially temperature (e.g. Beebee \& Griffiths, 2000), with consequent discontinuous cycles in both males and females. Examples of reproductive cycles of tropical species often show continuous cycles in both males and females with a short period of quiescence (e.g. lizards and snakes, Fitch 1970, 1982; lower vertebrates, Whittier \& Crews 1987), or seasonally associated with the wettest periods (Bufo bankorensis, Huang et al. 1996; Duttaphrynus (Bufo) melanostictus, Huang et al., 1997; amphibians and reptiles, Zug 1993; male tropical amphibians, Delsol et al., 1980, 1981, Delsol, 1995; amphibians, Exbrayat et al., 1998; Phrynobatrachus calcaratus, Gueydan-Baconnier, 1980; male tropical amphibians, Gueydan-Baconnier et al., 1984a, b; Amietophrynus (Bufo) regularis, Pujol, 1985, Pujol

*Corresponding author. Email: mraquet@univ-catholyon.fr 
\& Exbrayat, 1996, 2000, 2002; Amietophrynus (Bufo) mauritanicus, Kisserli \& Exbrayat, 2006, 2013, Kisserli et al. 2011). Studies on reproductive seasonality require a regular sampling of adults covering at least a complete year; consequently the accessible species have been more regularly studied than those with enigmatic or cryptic life styles. Caecilians (Amphibia: Gymnophiona) have largely been ignored since they have a cryptic, subterranean life style.

Gymnophiona are burrowing amphibians living in tropical areas (Sarasin \& Sarasin 1887-1890; Tonutti 1931; Taylor 1968; Duellman \& Trueb 1986; Exbrayat \& Estabel 2006); their body and most of their organs are elongated, with neither limbs nor girdles. In the oviparous Asian species, Ichthyophis beddomei and I. glutinosus sexual cycles are annual and discontinuous in both males and females (Seshachar, 1943; MasoodParveez, 1987; Masood-Parveez \& Nadkarni, 1993a, b; Exbrayat, 2006a; Bhatta et al. 2001). In the live-bearing South American species, Typhlonectes compressicauda and Dermophis mexicanus, sexual cycles are discontinuous, annual in males and biennial in females with pregnancy possible every other year (Wake 1980, 1995; Exbrayat et al. 1998; Exbrayat 1983, 1986, 1988a; Smita et al. 2006).

Boulengerula taitana is an oviparous species living in rich agricultural soils and in the indigenous forests of the Taita Hills, Kenya (Malonza \& Measey 2005; Malonza et al. 2010). The local climate is characterised by two dry and two wet seasons, with a single peak in temperature (Measey et al. 2009). In subterranean burrows B. taitana has been observed to lay eggs in November and December (Malonza \& Measey 2005; Measey et al. 2009).

Development of the altricial offspring is direct (Nussbaum \& Hinkel, 1994; Malonza \& Measey 2005), and mothers perform a particular kind of extended parental care (Kupfer et al. 2006). Spermatogenetic activity of this species has been recently described and is characterised by continuous gametogenesis, but with a slight seasonal increase in volume of testes during the long rainy season (March to May) (Measey et al. 2008). In Boulengerula taitana, ovarian structures and different categories of follicles have been previously described, including oogonia in germinal nests and postvitellogenic follicles, the corpus luteum and the atretic follicles (Raquet et al. 2007).

The present study attempts to clarify the ovarian activity, and to describe the reproductive cycle of female $B$. taitana. If production and maturation of follicles are continuous, ovulation should occur regularly throughout the year and so female sexual activity would be similar to that already described for males (Measey et al. 2008). Alternatively, female reproduction could be cyclic and could be influenced by climatic factors as previously described for other oviparous caecilians: Ichthyophis beddomei (MasoodParveez 1987; Masood-Parveez \& Nadkarni 1993a); Siphonops annulatus (Gomes et al. 2013); Ichthyophis cf. kohtaoensis (Kupfer et al. 2004). Using histological methods, the presence, relative number and developmental degree (according to Raquet et al. 2007) of each follicle type was examined in order to determine whether ovulation is seasonal or continuous. In addition, we investigated the implication of hormonal control by detection of steroid hormones, as previously conducted in other caecilians such as Ichthyophis beddomei (Masood-Parveez \& Nadkarni 1993b), and Typhlonectes compressicauda (Exbrayat \& Collenot 1983). Accordingly this method was used to localise sexual hormones in the ovary during the year, whereas immunohistochemistry was used in order to complete previous histological results (Raquet et al. 2007). 


\section{Materials ANd Methods}

\section{Climate}

The climate of the Taita Hills is monsoonal with two distinct wet periods and two other distinct dry periods. The rainy periods are the prolonged rains ("Masika") from March until May, and short heavy rains ("Vuli") from October until December. The dry seasons are respectively "Kaskazi" (January and February, $17 \mathrm{~mm}$ on average) and "Kusi" (from June until September, $57 \mathrm{~mm}$ on average). However, there is one single peak of temperature in February and a trough in July. Information on the area and variation in climatic regimes has been detailed elsewhere (see Measey et al. 2009; Fig. 1).

\section{Specimens}

Specimens of Boulengerula taitana were collected in the Taita Hills, near the town of Wundanyi $\left(03^{\circ} 24^{\prime} \mathrm{S} 38^{\circ} 22^{\prime} \mathrm{E}, 1420\right.$ m a.s.l.) between April 2003 and March 2004 by Malonza \& Measey (2005) with additional specimens collected in 2006. Specimens underwent lethal anaesthesia within the first 4 hours after capture with MS222, and the complete bodies were fixed in a formaldehyde solution (10\%) (Malonza \& Measey 2005). A selection of adult animals $(N=32$, three females for each month, except in July when no animals could be captured, and only a single individual in May) provided a representative sample for the present study. Sub-adults (less than $211 \pm 4.81 \mathrm{~mm}$ total body length before fixation [182-238 mm]) were eliminated from the sample. Length (to the nearest $\mathrm{mm}$ with a ruler) and mass (to the nearest $0.1 \mathrm{~g}$, with an electronic balance, CM 3201-1, Kern, Germany) were measured before and after fixation.

\section{Study of Ovaries}

The left ovary of each animal was extracted by dissection. Ovaries are situated in the midventral position, near the kidneys, associated with multi-lobed fat bodies. Large yellow eggs are scattered throughout the length of the ovary and can sometimes be observed through the skin of live females (GJM pers. obs.). Length and mass of each ovary were recorded, and biometric parameters, including those relative to length, mass and density index $\left(\mathrm{mg} / \mathrm{mm}^{2}\right)$, were established following the method developed by Exbrayat (1988b).

\section{Histology}

The samples were dehydrated in an ethanol series, cleared in butanol, embedded in paraffin wax and sectioned at $7 \mu \mathrm{m}$. Only one section in ten was stained with a topographic staining, Romeis' azan (Exbrayat 2001). A Nikon Eclipse E400 microscope was used to make the following observations and measurements using NIS-Element BR 3.0 (software). The maximal diameter of the largest follicles was recorded and the following histological structures enumerated: germinal nests, growing follicles, vitellogenic follicles, atretic follicles, corpora lutea. The number of germinal nests gave information about the quantity of oogonia. Corpora lutea with a central cavity or with stroma provided with a rich blood supply were also counted. Old corpora lutea and old atretic follicles undergoing the resorption process could not be distinguished, and so were excluded from counts. 


\section{Immunohistochemistry}

Selected sections were placed on an electrostatically charged slide. We used a LSAB kit (Dako) and two different primary Rabbit antibodies: an anti 17 -oestradiol (Chemicon, $\mathrm{AB}$ 934) and an antiprogesterone antibody (Abcys, AbC117-2478) to detect steroid hormones. Each section was first treated with hydrogen peroxidase solution in order to eliminate the endogenous peroxidase activity. A goat antirabbit serum was then applied for 60 min, followed by a secondary biotinylated antibody $(30 \mathrm{~min})$ that was combined with a streptavidin peroxydase complex. Labelling was performed with amino ethyl carbazol (Dako AEC substrate chromogen 2010-10 K364). Immunohistochemical controls without primary antibodies were made in order to determine specific and non-specific responses. Two or three slides per month were used, except July (0) and May (1).

\section{Results}

\section{Gross Morphology and Ovarian Biometric Data}

The average length of females was $244.8 \pm 6.03 \mathrm{~mm}$ after fixation. Variance analysis did not show any significant difference in length of females collected during the year $(N=29$, $\operatorname{Pr}>\mathrm{F}: 0.143)$. Female body mass was $4.68 \pm 0.34 \mathrm{~g}$, also without significant difference through the year $(N=29, \operatorname{Pr}>\mathrm{F}: 0.119)$.

Ovaries were $38.97 \pm 3.23 \mathrm{~mm}$ length, with a mass of $28.74 \pm 10.83 \mathrm{mg}$ (relative length is $16.14 \pm 1.37$; relative mass $0.60 \pm 0.21$, and density index $1.644 \pm 0.418 \mathrm{mg} / \mathrm{mm}^{2}$ ). Variance analysis showed that the ovarian mass $(N=29, \operatorname{Pr}>\mathrm{F}: 0.046)$ and the density index $(N=29, \operatorname{Pr}>\mathrm{F}: 0.005)$ were significantly variable throughout the year with maximal values from December to February. A histogram of ovarian mass showed an initial period with the lowest average mass, from March until November $(17.62 \pm 6.28 \mathrm{mg})$, followed by a period with the highest average ovarian mass, from November until February $(43.6 \pm 25.85 \mathrm{mg})$, with a peak in December. In this second period, each monthly ovarian mass showed a large confidence interval: $17.07 \mathrm{mg} \pm 10.90$ for November ovarian mass, $87.4 \mathrm{mg} \pm 59.05$ in November, $32.5 \mathrm{mg} \pm 18.34$ in December, $37.47 \mathrm{mg} \pm 32.06$ in January and $37.47 \mathrm{mg} \pm 32.06$ in February (Fig. 1).

\section{Seasonal Effects on Ovaries during the Reproductive Cycle in Boulengerula taitana Ovaries}

Irrespective of annual cycles in ovulation, other processes within the ovaries such as folliculogenesis, vitellogenesis, and atresia continued throughout the year. Here, we describe this continuous variation observed in the ovaries of Boulengerula taitana, categorising them into stages according to Exbrayat (2006b), and then investigate whether there is any evidence for seasonal changes in any of these stages (Table 1).

The germinal nests contained 10 to 20 oogonia $(15-30 \mu \mathrm{m}$ in diameter, stage A) and sometimes an early follicle with a single layer of flattened connective cells $(40 \mu \mathrm{m}$ large, stage B). This ellipsoidal follicle increased in size $(300-800 \mu \mathrm{m})$ and possessed a second layer (granulosa); at this stage (growing follicles, stage C), the nucleus of oocyte was equipped with many nucleoli and lampbrush chromosomes. When the follicle exceeded $800 \mu \mathrm{m}$ in diameter, the first yolk platelets invaded the peripheral cytoplasm 

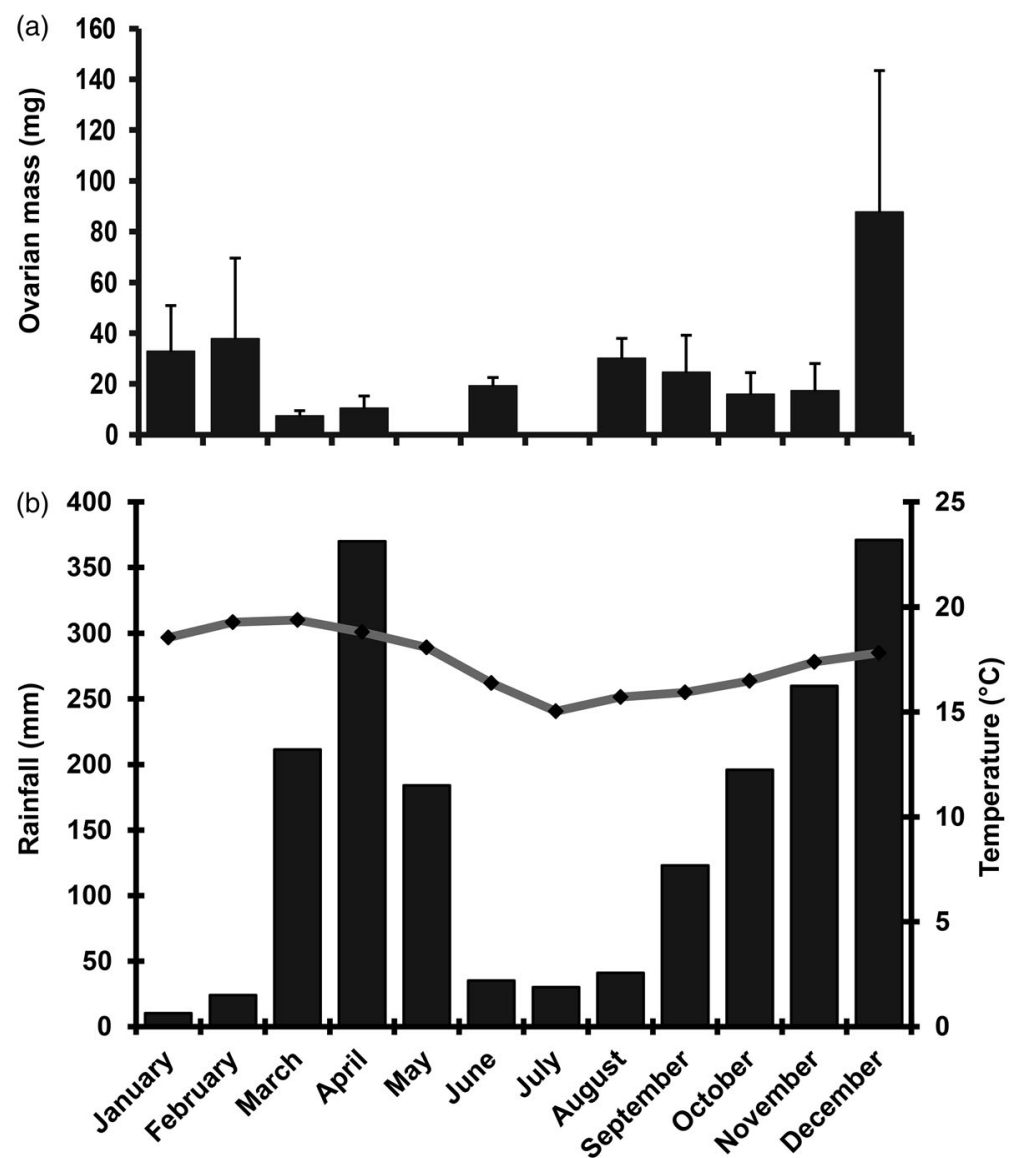

Figure 1. A: Histogram of monthly variation of ovarian mass in Boulengerula taitana (mg). Error bars represent the standard deviations. B: Climatic data. Bars are rainfall $(\mathrm{mm})$; line is temperature $\left({ }^{\circ} \mathrm{C}\right)$ from Measey et al. (2009).

of the oocyte, increasing in number and size, especially at the vegetal pole. At the end of vitellogenesis, granulosa cells became cubical and follicles were more than $2 \mathrm{~mm}$ in diameter (vitellogenic follicles, stage D). If ovulation occurred, the follicle epithelium invaded the free central place left by the ovulated oocyte and formed a corpus luteum (stage F). If not, granulosa cells grew in number and phagocytised the oocyte (atretic follicle, stage E). At the end of both processes, follicle structures were resorbed progressively into the connective tissue (Table 1). The number of germinal nests per ovary was found to be $16.9 \pm$ 3.76 [4-76]. Follicles were absent, or the first follicle (stage B) was detected in a single germinal nest. The average number of growing follicles (stage C) was $36.23 \pm 4.32$ [17-55]. Vitellogenic follicles (stage D) did not exceed 17 per ovary with an average of $7.37 \pm 1.39$. We counted $0.93 \pm 0.37[0-3]$ atretic follicles (stage E) per ovary and 0.67 $\pm 0.43[0-4]$ young corpora lutea (stage F).

Monthly variation of the follicle categories is summarised in Table 2. Stages A, C and D had a similar profile (Fig. 2A). Figure 2B shows variation in postvitellogenic follicles. However only the number of stage D (vitellogenic follicles) among preovulated follicles 
Table 1. Principal characteristics of the different stages (A to F) of follicle evolution in B. taitana.

\begin{tabular}{|c|c|c|c|c|c|c|}
\hline Follicle stages & Oogonia A & First follicle B & $\begin{array}{l}\text { Growing } \\
\text { follicle } \mathrm{C}\end{array}$ & Vitellogenic follicle D & Atretic follicle E & Corpus luteum $\mathrm{F}$ \\
\hline $\begin{array}{l}\text { Size }(\mu \mathrm{m}) \text { and } \\
\text { form }\end{array}$ & 13 Round & 40 Round & $\begin{array}{l}>400 / 300 \\
\quad \text { Ellipsoidal }\end{array}$ & $\begin{array}{l}\text { From } 700 / 800 \text { to }>2000 \\
\text { Ellipsoidal }\end{array}$ & As early stage $\mathrm{D}$ & \\
\hline Epithelium & None & Monolayer & $\begin{array}{l}\text { Double layer } \\
\text { Theca and } \\
\text { granulosa }\end{array}$ & $\begin{array}{l}\text { Double layer Zona } \\
\text { pellucida Granulosa } \\
\text { turns into high Theca } \\
\text { with blood vessels }\end{array}$ & $\begin{array}{l}\text { Thickened With diverse cell } \\
\text { categories (mastocytes, } \\
\text { adipocyte-like cells) } \\
\text { proliferation of granulosa }\end{array}$ & $\begin{array}{l}\text { Thickened Granulosa cells } \\
\text { differentiated into luteal } \\
\text { cells Theca cells } \\
\text { proliferate }\end{array}$ \\
\hline Interpretation & & Folliculogenesis & & Vitellogenesis & Atresis & Luteinisation \\
\hline
\end{tabular}


Table 2. Monthly variation of follicle numbers, maximal diameters $(\mu \mathrm{m})$ and total numbers of follicles within the different categories.

\begin{tabular}{|c|c|c|c|c|c|c|c|c|c|c|c|}
\hline & January (3) & February (3) & March (3) & April (3) & May (1) & June (3) & August (3) & September (3) & October (3) & November (3) & December (3) \\
\hline $\begin{array}{l}\text { Germinal nest } \\
\text { Stage A }\end{array}$ & $28.67 \pm 6.82$ & $20 \pm 22.6$ & $19.67 \pm 10.69$ & $12 \pm 7.92$ & 26 & $23.33 \pm 9.89$ & $22 \pm 13.05$ & $18.67 \pm 7.27$ & $9.67 \pm 7.53$ & $5.67 \pm 1.31$ & $9.33 \pm 1.31$ \\
\hline $\begin{array}{l}\text { First follicle } \\
\text { Stage B }\end{array}$ & $1 \pm 1.3$ & $5 \pm 5.66$ & $1.67 \pm 2.35$ & $0.33 \pm 0.65$ & 20 & $6.67 \pm 5.69$ & $2 \pm 3.92$ & $8.33 \pm 7.95$ & $1 \pm 1.31$ & 0 & $0.33 \pm 0.65$ \\
\hline $\begin{array}{l}\text { Growing follicle } \\
\text { Stage C }\end{array}$ & $48 \pm 6.88$ & $\begin{array}{l}30.67 \pm \\
23.124\end{array}$ & $30.67 \pm 8.64$ & $23.67 \pm 6.43$ & 69 & $42.67 \pm 2.13$ & $43.33 \pm 10.99$ & $40.33 \pm 8.34$ & $39 \pm 7.07$ & $29.67 \pm 21.03$ & $29.33 \pm 4.57$ \\
\hline $\begin{array}{l}\text { Vitellogenic follicles } \\
\text { Stage D }\end{array}$ & $6.67 \pm 4.71$ & $10 \pm 3.92$ & $4 \pm 5.18$ & $5 \pm 3.19$ & 14 & $14.33 \pm 2.84$ & $\begin{array}{c}7.675 .33 \pm \\
5.35\end{array}$ & $7.33 \pm 41.31$ & $5.67 \pm 2.61$ & $5.67 \pm 0.657$ & $7.33 \pm 1.73$ \\
\hline $\begin{array}{l}\text { Atretic follicles } \\
\text { Stage E }\end{array}$ & $2.33 \pm 0.64$ & $1 \pm 1.13$ & $2.33 \pm 0.65$ & $0.67 \pm 0.65$ & 10 & $1 \pm 1.13$ & 0 & $0.67 \pm 0.65$ & $1.33 \pm 1.73$ & 0 & 0 \\
\hline $\begin{array}{l}\text { Corpora lutea } \\
\text { Stage F }\end{array}$ & $2.33 \pm 0.653$ & $1.33 \pm 2.61$ & 0 & 0 & 0 & 0 & 0 & 0 & 0 & $0.67 \pm 0.65$ & $1.67 \pm 2.35$ \\
\hline $\begin{array}{l}\text { Maximal follicle } \\
\text { diameter }\end{array}$ & $\begin{array}{c}1518.67 \pm \\
630.22\end{array}$ & $2148 \pm 346.4$ & $\begin{array}{c}1305.5 \pm \\
133.62\end{array}$ & $\begin{array}{c}1685.33 \pm \\
1022.24\end{array}$ & 1444.44 & $\begin{array}{c}1851.67 \pm \\
158.35\end{array}$ & $1981.67 \pm 202$ & $\begin{array}{c}2518.33 \pm \\
836.95\end{array}$ & $\begin{array}{c}2856.67 \pm \\
676.72\end{array}$ & $\begin{array}{c}1729.67 \pm \\
1380.43\end{array}$ & $\begin{array}{l}2745 \pm \\
698.57\end{array}$ \\
\hline Total number & $44.67 \pm 27.12$ & $51.67 \pm 43.44$ & $38.33 \pm 13.69$ & $28.33 \pm 8.49$ & 86 & $62.67 \pm 3.46$ & $50.67 \pm 12.72$ & $55 \pm 4.93$ & $47 \pm 7.07$ & $23 \pm 1.13$ & $38.33 \pm 6.82$ \\
\hline
\end{tabular}


(a)

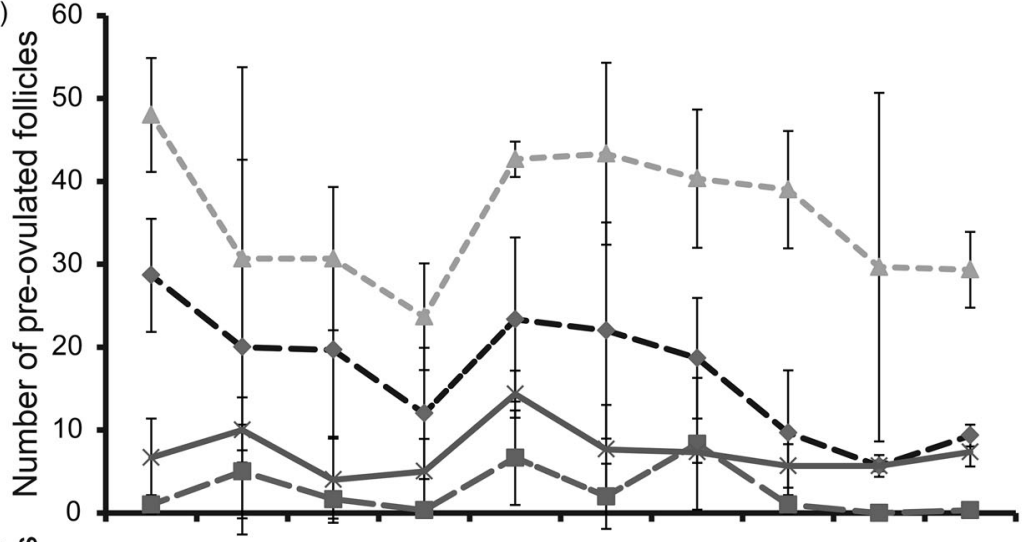

(b) $\stackrel{\mathscr{d}}{0}$

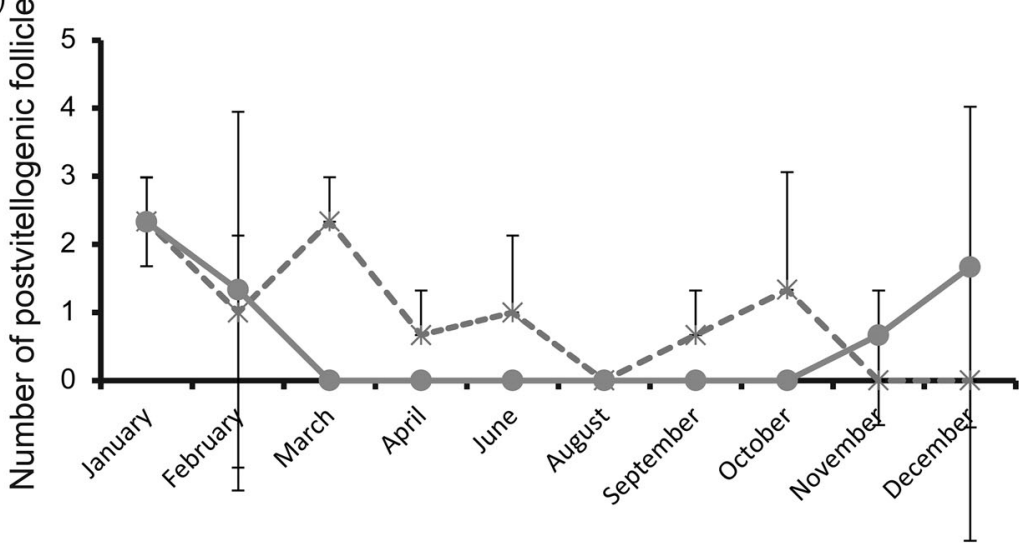

Figure 2. A: Monthly variation of pre-ovulated follicle numbers (black dotted line $=$ stage A or germinal nest, grey line with long dots $=\mathrm{B}$ or first follicle, grey line with small dots $=\mathrm{C}$ or growing follicle, continuous line $=\mathrm{D}$ or vitellogenic follicle). Error bars represent the standard deviations. B: monthly variation of postvitellogenic follicle numbers (dotted line $=$ stage $\mathrm{E}$ or atretic follicle, continuous line $=\mathrm{F}$ or corpus luteum. Error bars represent the standard deviations.

was significantly different through the months $(N=30, \operatorname{Pr}>\mathrm{F}: 0.035)$. The curve shows a peak in February and June (Fisher test between April and June: $\operatorname{Pr}>\mathrm{F}: 0.001$, FebruaryMarch Pr $>$ F: 0.017). After February a steep reduction until April was observed, and after June, a slow decline was found until November. Atretic follicles (stage E) (ANOVAs, $N=30, \operatorname{Pr}>\mathrm{F}$ : 0.005 ) presented a significant peak in January and in March (Fisher test: January-February $\operatorname{Pr}>\mathrm{F}$ : 0.042, March-April 0.013). Young corpora lutea were not recognisable between March and October. In November and December, two thirds of females possessed corpora lutea. In January and February, corpora lutea were observed in all and one third of females, respectively. In the single females captured in November-December with an egg clutch, no corpus luteum was detected in ovaries (Fig. 2B).

The analysis of variance between the four seasons showed a significant variation for all the categories (ANOVAs, $N=30, \alpha=0.05$. Stage A, $\operatorname{Pr}>\mathrm{F}$ : 0.006; stage B, $\operatorname{Pr}>\mathrm{F}: 0.023$; stage $C, \operatorname{Pr}>F$ : 0.035; stage D, Pr $>$ f: 0.038; stage E, Pr $>F$ : 0.04; stage F, Pr $>F$ : 0.023). 

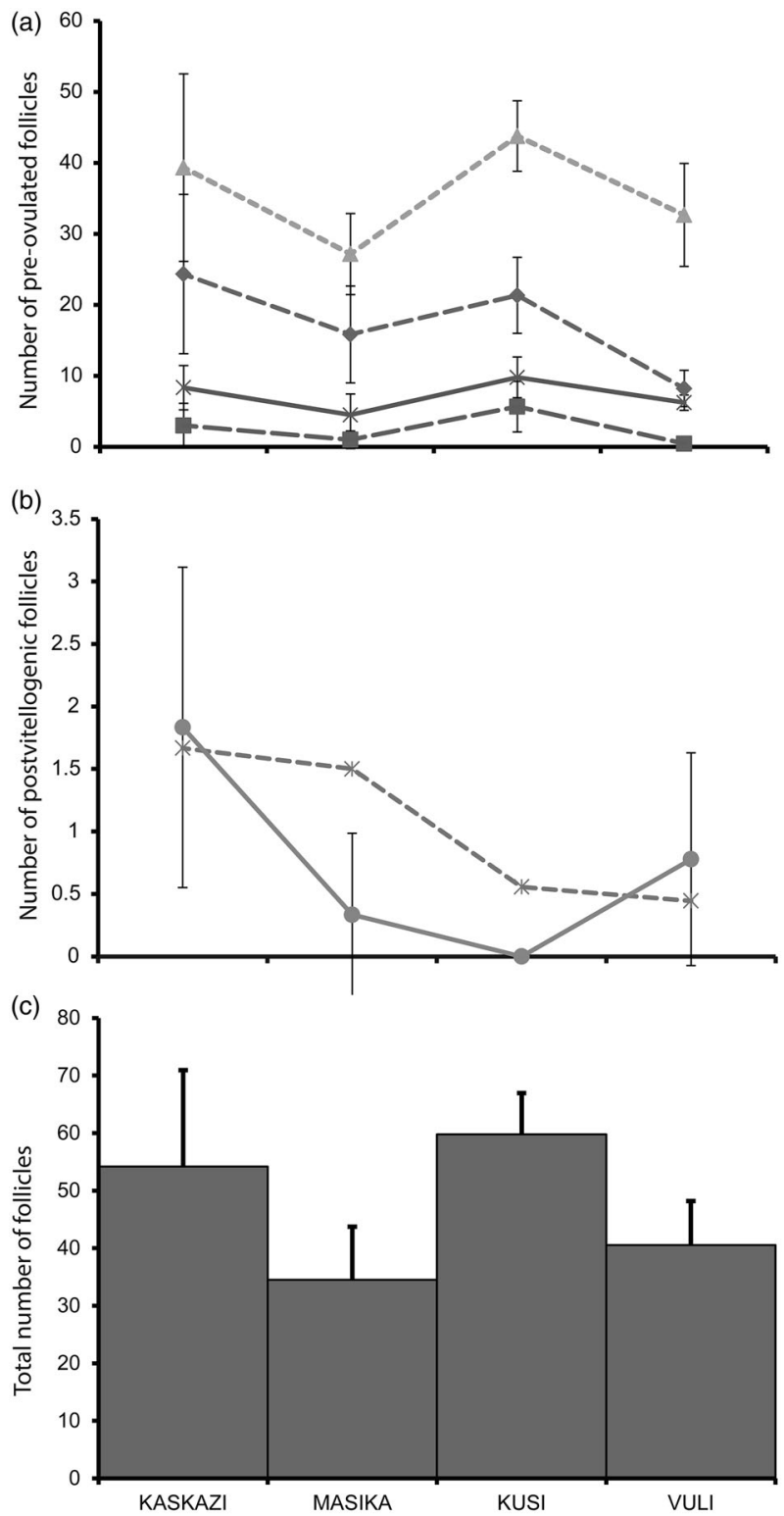

Figure 3. A: seasonal variation of pre-ovulated follicle numbers (dashed line $=$ stage $\mathrm{A}$ or germinal nest, longer dashed line $=\mathrm{B}$ or first follicle, dotted line $=\mathrm{C}$ or growing follicle, continuous line $=\mathrm{D}$ or vitellogenic follicle; Kaskazi $=$ January-February, Masika $=$ March-May, Kusi $=$ June-September, Vuli $=$ October-December). Error bars represent the standard deviations. B: seasonal variation of postvitellogenic follicle number (dotted line $=$ stage $\mathrm{E}$ or atretic follicle, continuous line $=\mathrm{F}$ or corpus luteum). Error bars represent the standard deviations. C: seasonal variation of total number of follicles. Error bars represent the standard deviations. 
Similar curves were registered for seasonal variations of the follicles. Kaskazi (January and February) and Kusi (June-September) corresponded to a peak of preovulated follicles (Fig. 3A). Atretic follicles were maximal in number in Kaskazi and Masika whereupon a progressive decrease was observed until Vuli (October-December) and Kusi at which the number of atretic follicles attained the minimum. Young corpora lutea disappeared in Masika and Kusi (Fig. 3B). No significant difference was registered among preovulated follicles between Vuli and Kaskazi (Fig. 3A).

\section{Other Parameters and Data Studied}

Females with eggs in oviducts or collected with eggs already laid were only observed from November until February (7 observations between 2002 and 2005, Malonza \& Measey 2005).

The average total number of follicles was $47.6 \pm 5.13$ per ovary [34.5-59.78] and ranged from 21 to 84 . ANOVA revealed that the mean number of follicles did not change during the year $(N=30, \operatorname{Pr}>\mathrm{F}: 0.058)$, although a significant change was detected among the seasons $(N=30, \operatorname{Pr}>\mathrm{F}$ : 0.006; Table 1, Fig. 4). In Kaskazi and Kusi, ovaries possessed a relatively high number of follicles. In Masika and Vuli, follicles were less numerous (see Fig. 4 and Table 2A).

The average maximum diameter of mature follicles was $2.06 \pm 0.23 \mathrm{~mm}$ and they were not found to vary significantly throughout the year $(N=29, \operatorname{Pr}>\mathrm{F}: 0.136)$, but maximal values were observed in females captured in September (Table 1).

\section{Hormone Detection in Ovaries}

The hormones $17 \beta$-oestradiol and progesterone were detected using immunochemical techniques in the cytoplasm and nuclei of all the different follicular cell types (Fig. 5A and B). A signal was observed throughout the year, especially in atretic follicles and corpora lutea. In oogonia, a signal for progesterone was observed from March until August.

Immunohistological detection of 17及-oestradiol.-The percentages of labelled nuclei varied according to the ovarian structures and period of year. In stroma cells of germinal nests, $18 \%$ of nuclei were labelled from September until February and only $5 \%$ in other months; $20-40 \%$ of oogonia nuclei were labelled during the year except in September and in October - a period in which the percentage strongly increased (about $85 \%$ ). In mature vitellogenic follicles, the percentage of labelled nuclei was comparable in the theca and granulosa (30-40\%) from March until October. From November until February, the label affected $20 \%$ of theca nuclei and $50 \%$ of granulosa nuclei. In atretic follicles, labelling was different in wall and internal cells. Throughout the year, $20 \%$ of nuclei of the first cells were labelled. In contrast $42 \%$ of nuclei of internal cells were labelled except from March until August when the label affected only $17 \%$ of nuclei.

Immunohistological detection of progesterone.-In germinal nests, labelled nuclei of stroma cells were only observed in September and October. In contrast $50-70 \%$ of nuclei were labelled in oogonia except from November until February (30\%). Throughout the year, 30-45\% of nuclei of vitellogenic granulosa cells were labelled, the highest level 

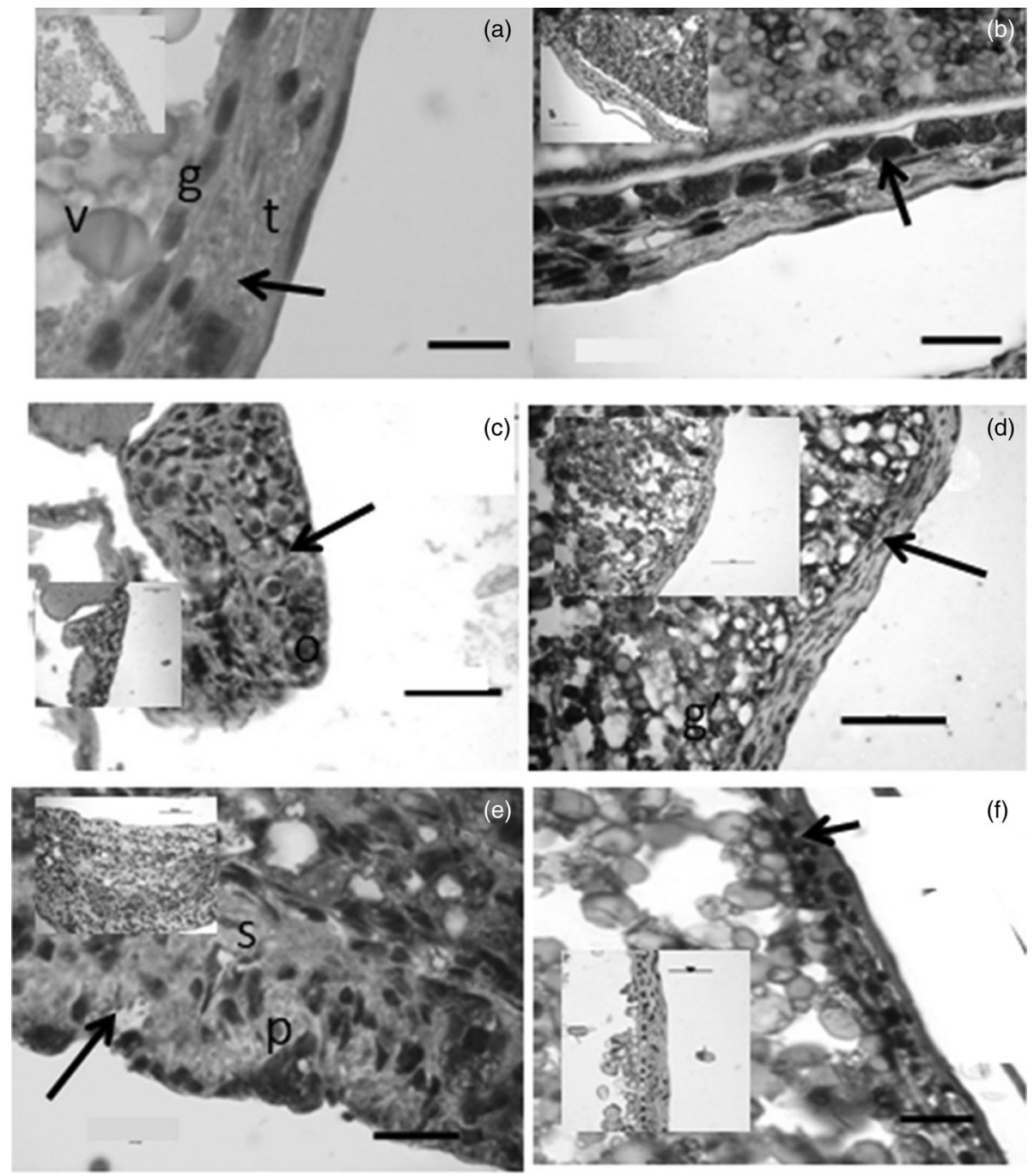

Figure 4. 17ß-oestradiol immunodetection. A: vitellogenic follicle, February. B: mature vitellogenic follicle, November; C: germinal nest, January. D: atretic follicle, December. E: old corpus luteum, November, $\mathrm{p}=$ peripheral cells. F: vitellogenic follicle, June. Scale bars: $20 \mu \mathrm{m}$ (A, B, E); $50 \mu \mathrm{m}$ $(\mathrm{C}, \mathrm{D}, \mathrm{F})$. The arrows indicate histochemical labels. The inset figures correspond to the negative control without primary antibody. $\mathrm{G}=$ granulosa; $\mathrm{g}^{\prime}=$ granulosa cells in proliferation; $\mathrm{o}=$ oogonia; $\mathrm{s}=$ stroma; $\mathrm{t}=$ theca; $\mathrm{v}=$ vitellin platelets.

being registered from March until August. 20-35\% of theca nuclei were labelled, the lowest level being found from March until August. In atretic follicles throughout the year, except in September and October, the percentage of labelled nuclei was 30-40\% in external cells and 47-51\% in internal cells. In September and October they were 15\% and $33 \%$, respectively. In corpora lutea, the percentages of marked nuclei in external and internal cells were comparable with $30-35 \%$ for $17 \beta$-oestradiol and $15 \%$ for progesterone. 

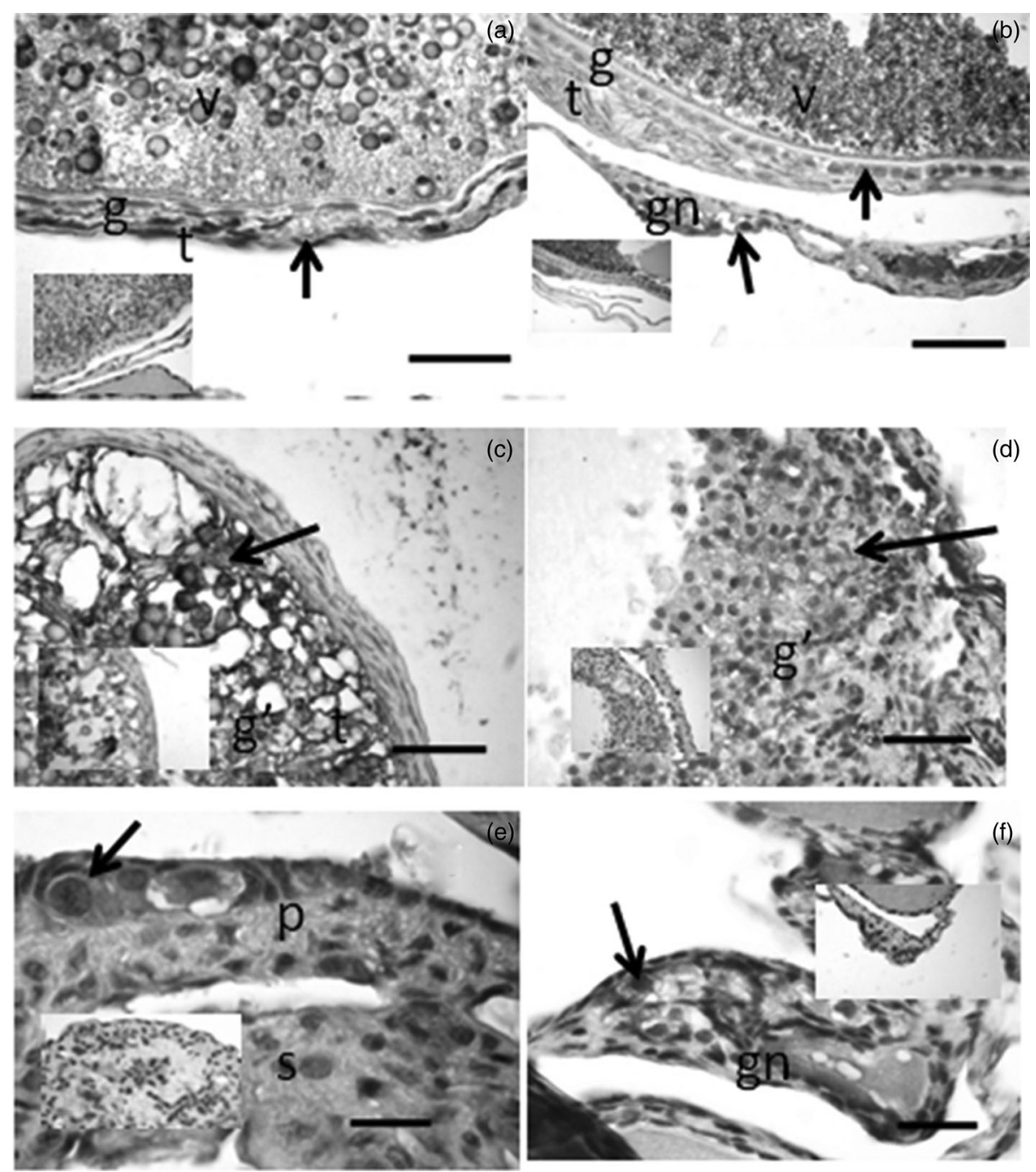

Figure 5. Progesterone detection. A: vitellogenic follicle February; B: mature vitellogenic follicle, November; C: atretic follicle, in formation, December; D: corpus luteum, February; E: old corpus luteum, January; F: germinal nest, April. Scale bars: $50 \mu \mathrm{m}$ (A, B, C, D); $20 \mu \mathrm{m}$ (E, F). The arrows indicate histochemical labels. The inset figures correspond to the negative control without primary antibody. $\mathrm{f}=$ follicle; $\mathrm{g}=$ granulosa; $\mathrm{g}$ '= cells from granulosa in proliferation; $\mathrm{gn}=$ germinal nest; $\mathrm{p}=$ peripheral cells, $\mathrm{s}=$ stroma; $\mathrm{t}=$ theca; $\mathrm{v}=$ vitellin platelets.

\section{Discussion}

\section{Reproductive Cycle}

Variations in stages E and F (post ovulated follicles) did not appear to correspond with temperature or rainfall (Fig. 3B). The presence of atretic follicles was discontinuous during the year and the measures presented high confidence intervals especially in February and in October. 
The lack of any significant monthly variation for the first stages of follicle production (stages $\mathrm{A}$ to $\mathrm{C}$ ) throughout the year, and the correlations between the number of germinal nests and stage $\mathrm{B}$ and $\mathrm{C}$ follicles suggest a continuous production of follicles in Boulengerula taitana. The variation in the number of germinal nests could be an artefact related to the method of counting from transverse sections (only one section in ten was considered). When germinal nests are less developed, especially in November or December, they could be missed. On the other hand, when they are more developed, they could be counted twice. However the number of germinal nests counted did provide information about ovarian activity.

The vitellogenesis as well as the formation of atretic follicles appeared to be variable throughout the year. In contrast, variations of all other follicle categories appeared to be distinctly seasonal. Moreover rainfall and temperature curves can be superimposed on the preovulated follicles. Follicle production increased during the two dry seasons (Kaskazi and Kusi). The peak of stages A, B, C and D corresponded to the minimal temperatures observed in Kusi. Young corpora lutea were present only from November to February i.e. in the short dry season and the short rainy season (Kaskazi and Vuli). These observations underpin the distinct seasonal activities of the ovary for this species.

Ovarian mass and information about corpora lutea allowed us to determine the period at which ovulation occurs. Ovarian mass is strongly correlated with the presence of large follicles (with a maximal diameter) and consequently provides information about the activity of the ovary. Two phases of activity were observed: first with high ovary masses from November until February (inclusive), indicating the presence of several females with eggs ready to be laid. During this period, large confidence intervals showed a high disparity between females and suggested that some of them had already ovulated, and consequently their ovary mass was therefore low. In turn, other females with heavy ovaries had yet to ovulate. Data collected in situ or after dissection confirmed this hypothesis. Indeed, when ovary mass was low, eggs were detected in the oviducts, or eggs were found in the chamber where the individuals were sampled (see Malonza \& Measey 2005). In other specimens, ovaries were massive, with big follicles, but without any eggs in the oviduct.

The onset of young corpora lutea development during the short rainy season (Vuli) indicates the beginning of ovulation. Thus the ovulation pattern can be summarised as follows: ovulation begins in November, increases with a peak in January, and ends in February. As a result of this study, we can assume that only the presence of young corpora lutea was directly informative about the period of ovulation.

This study also suggests that the sexual cycle of female Boulengerula taitana appears to be annual with a single ovulation period distinct from the rest of the year: ovulation continues over a period of four, perhaps five, months (November to February).

Studies of testicular histology in Boulengerula taitana (Measey et al. 2008) showed a continuous production of male gametes. The volume of testes increased especially between Kusi and Vuli before decreasing again. A second reduction of size in testes was detected after Masika, suggesting a period of mating activity during Kaskazi. In females, the ovulation followed the same pattern and occurred in Vuli and in Kaskazi. Even if egg-laying and mating were observed in situ only in Vuli (November and December), it appears that both these activities occurred during a much longer period of the year. The results of these studies are complementary to those of Measey et al. (2008), suggesting a synchronisation of testicular and ovarian activities. 
Even though we observed two periods of decreasing numbers of germinal nests (growing and vitellogenic follicles from January until June), corresponding with the onset of each rainy season, ovulation occurred only at the end of the second period. Thus, we conclude that rainfall did not determine the timing of ovulation. The increase in maximum diameter of follicle and ovarian mass (and eventually the presence of corpora lutea) determined the upturn in ovarian activity which started at the beginning of the long dry season Kusi, around June, which is characterised by minimum temperatures. Therefore, the primary factor regulating the breeding behaviour appears to be the ambient temperature, as in spermatogenic activity (Measey et al. 2008).

The maturation of vitellogenic follicles up to ovulation coincided with the beginning of rainfall and increased temperature after the long dry season (Kusi). Presumably, food becomes more abundant, and animals migrate towards the surface for mating (see Measey \& Barot 2006). During the short dry season (Kaskazi), females provide an extended maternal care to their young (Kupfer et al. 2006). Egg-laying was observed in situ during the short rainy season (Vuli) but it could also occur during the following short dry season (from January until beginning of March).

This study suggests that Boulengerula taitana is yet another caecilian in which females display a clear annual cycle, while male testicular activity is aseasonal. Wake (1995) previously highlighted this paradox of many caecilian species, prompting the same important questions concerning the decoupling of mating and egg-laying in this and other caecilian species.

Oogenesis and folliculogenesis can be considered to be continuous throughout the year. Out of the ovulation period, vitellogenesis is only regulated by the atresia process. During the ovulation period, confidence intervals were often close to the mean (see Figure 1). This feature suggests that a portion of females in the population was not ready to breed in November or December, and may only lay their eggs in January or February, or perhaps skip a year. Our sample size was not great enough to determine whether this could be related to size.

Body size is a parameter that appears to act on ovarian maturity: the longer (and presumably older) a female, the earlier ovulation occurs. Thus females collected in November and December which had ovulated, were larger than expected.

Vitellogenic follicles of B. taitana are smaller in size than that of Ichthyophis beddomei (1400 versus $7500 \mu \mathrm{m}$ in diameter) but they are comparable to those of Chthonerpeton indistinctum with approximately $2000 \mu \mathrm{m}$ (Masood-Parveez 1987; Berois \& De Sa 1988; Masood-Parveez \& Nadkarni 1993a, b).

Generally, mature follicles of viviparous species are smaller than follicles of the oviparous caecilians (Exbrayat \& Delsol 1988). Mature as well as young follicles can degenerate with atretic processes. Zona pellucida is often observed in atretic follicles, but not in Ichthyophis beddomei (Masood-Parveez 1987; Masood-Parveez \& Nadkarni 1993b), or in Typhlonectes compressicauda (Exbrayat 1983, 1986; Exbrayat \& Collenot 1983).

The first phase of luteinisation is similar to that in Typhlonectes compressicauda. Female caecilians generally possess corpora lutea, showing embryo development starts during transit into the oviduct (Wake 1968, 1977; Exbrayat \& Collenot 1983; Exbrayat 1983, 1986; Masood-Parveez 1987).

Boulengerula taitana exhibits an annual reproductive cycle resembling other oviparous caecilians (Wake 1983; Jared et al. 1999; Exbrayat 2006a; Beyo et al. 2007) with several similarities with Ichthyophis beddomei (Masood-Parveez 1987; Masood-Parveez \& 
Nadkarni 1993a). However, mature follicles are less numerous in B. taitana with an average of $5.5 \pm 0.9[0-14]$ than in Ichthyophis glutinosus: 12-40 (Exbrayat \& Delsol 1988). The number of laid eggs of Boulengerula taitana with a maximum of eight is very low and can be compared to Idiocranium russelli with six eggs (Wake 1977), while other oviparous species like I. kohtaoensis have an average of 34.8-40.9[22-58] eggs (Kupfer et al. 2004) or I. malabarensis, which lays more than 100 eggs (Seshachar et al. 1982). Among viviparous species, reproductive cycles have been studied in Typhlonectes compressicauda (Exbrayat \& Collenot 1983; Exbrayat 1983, 1985, 1986, 1988a, b) and Dermophis mexicanus (Wake 1977, 1980). The reproductive cycle of both of these species appears to be biennial. Several similarities were recorded between these two species, especially the consistent number of follicle categories, and the presence of corpora lutea in females when eggs are present in the oviduct until egg-laying. Gametogenesis activity in $B$. taitana does not completely stop during the annual cycle, contrary to the other caecilians studied (Wake 1995; Smita et al. 2006). This is in agreement with the conclusion of Measey et al. (2008) regarding the continuous spermatogenesis of males.

In most oviparous gymnophionan species, eggs are laid during the rainy season, when hydric and trophic factors are appropriate (Wake \& Dickie 1998). In Ichthyophis glutinous, egg-laying is observed from May until September, during the time of the monsoon. In the viviparous South American species Chthonerpeton indistinctum (Barrio 1969), Dermophis mexicanus (Wake 1980) and Typhlonectes compressicauda (Exbrayat 1986, 2000; Exbrayat \& Flatin 1985), reproduction occurs when food is also abundant. Boulengerula taitana seems to be an exception. The main factor affecting its reproduction appears to be an annual peak in temperature. If hydric conditions are not a limiting factor for reproduction in this species, high temperatures may represent optimal growing conditions for the altricial young and their energetically costly period of extended female care (Kupfer et al. 2006).

\section{Ovarian Endocrinology and Corpora Lutea Persistence}

High granulosa cells were labelled throughout the year, confirming their secretory histological aspect. Granulosa cells synthesise $17 \beta$-oestradiol, and continue when the cells proliferate into atretic follicles or in luteal cells. The surrounding tissues are labelled because of the passive diffusion of this liposoluble steroid hormone.

Immunohistological study suggested the presence of $17 \beta$-oestradiol and progesterone in the ovary throughout the year, showing a continuous production of steroids related to the continuous folliculogenesis. Out of the reproductive period, the steroid hormones were synthesised by vitellogenic and atretic follicles. The fact that an immunohistological signal was observed in the cytoplasm of all the ovarian tissues can be related to the in situ synthesis of hormones and their diffusion. The hypothesis of metabolic hormonal action in cytoplasm is not excluded by our study (Baumann et al. 1999; Pelletier 2000; Pelletier et al. 2000; Cato et al. 2002; Acconcia \& Kumar 2006; Kumar et al. 2006; Zhao et al. 2008; Fox et al. 2009). Nevertheless, the presence of an immunohistological signal suggests both autocrine and paracrine actions. The nuclear label corresponds to the hormone linked with its receptor on DNA. We therefore deduce that the hormone has an effect on cellular activity. Labelled nuclei of granulosa cells suggest oestradiol exerted a feedback on its synthesis especially during the period of ovulation (Hunter \&Armstrong 1987). 
The lack of progesterone detection in oogonia from March to August suggests that a progesterone control of gametogenesis occurs during the year, explaining the decrease of gametogenesis between March and August. The decrease of 17 $\beta$-oestradiol labelling in germinal nests in the same period also suggests a similar action of this steroid (Lioutas et al. 1997).

Endocrine activity has been little studied in Gymnophiona. In viviparous Typhlonectes compressicauda, estriol and $17 \beta$-oestradiol were detected in the granulosa of mature follicles. The enzyme participating in steroidogenesis $\delta 5-3 \beta$ hydroxysteroide dehydrogenase (HSDH) is present in granulosa and in internal theca of previtellogenic and vitellogenic follicles, in cells originated from granulosa in young corpus luteum and atretic follicles (Exbrayat 1986, 2006a; Exbrayat \& Collenot 1983). Both HSDH and 17ßHSDH were detected in Ichthyophis beddomei in granulosa cells of previtellogenic and vitellogenic follicles, and in atretic follicles (Masood-Parveez 1987). Our results confirm the correlation between ovarian follicle activity (folliculogenesis, vitellogenesis and ovulation) and steroid hormone production in Boulengerula taitana, as in other vertebrates. In B. taitana, 17ß-oestradiol was detected throughout the year in high granulosa cells (mature oocytes), in theca cells and derived cells. These observations are consistent with the hypothetical continuous production of follicles during the year. Moreover, 17 $\beta$-oestradiol is produced by the follicle wall as soon as vitellogenesis occurs. After ovulation, oestradiol synthesis continues mostly in atresis. The follicle is the first site of progesterone biosynthesis. Then luteal cells take over from synthesis especially when they are numerous in young corpora lutea. Progesterone is implicated in the development of the oviduct. After ovulation, steroid detection defines several reabsorbed structures such as old corpora lutea. Their persistence in Boulengerula taitana may be correlated with the presence of eggs in oviducts, direct embryonic development and parental care. Even though this species is oviparous, there are similar particularities with viviparous Typhlonectes compressicauda in which corpora lutea do not disappear after ovulation.

\section{ACKnowledgements}

We would like to thank Patrick Malonza, field assistants and land-owners in Kenya for facilitating collections of material used in this study.

\section{REFERENCES}

Acconcia, F. \& R. Kumar. 2006. Signaling regulation of genomic and nongenomic functions of estrogen receptors. Cancer Letters 238: 1-14.

BARRIO, A. 1969. Observaciones sobre Chthonerpeton indistinctum (Gymnophiona, Caeciilidae) y su reproduccion. Physis 28: 499-503.

Baumann, C.T., C.S. Lim \& G.L. Hager. 1999. Intracellular localization and trafficking of steroid receptors. Cell Biochem. Bioph. 31: 119-127.

Beebee, T.J.C. \& R.A. Griffiths. 2000. Amphibians and Reptiles. Collins, London.

Berois, N. \& R. De SA. 1988. Histology of the ovaries and fat bodies of Chthonerpeton indistinctum. J. Herp. 22: 146-151.

Beyo, R.S., P. Sreesith, L. Divya, O.V. Oommen \& M.A. Akbarsha. 2007. Assembly of ovarian follicles in the caecilians Ichthyophis tricolor and Gegeneophis ramaswamii: light and transmission electron microscopic study. Zygote. 15: 199-213.

Bhatta, G.K., E. Anjubault \& J.M. Exbrayat. 2001. Structure et ultrastructure des testicules d'Ichthyophis beddomei (Peters, 1879), Amphibien Gymnophione. Ann. Mus. Havre. 67: 11-12. 
Cato, A.C., A. Nestl \& S. Mink. 2002. Rapid actions of steroid receptors in cellular signalling pathways. Sci. Sign. 138: re9.

Delsol, M. 1995. Appareil génital femelle. Anatomie, histologie, cycle annuel et déterminisme du cycle. Pp. 1231-1253. In P.P. Grassé \& M. Delsol (Eds) Traité de Zoologie, XIV, fascicule I-A. Masson, Paris, Milan, Barcelone.

Delsol, M., M. Gueydan-Baconnier, F. Neyrand De Leffemberg \& P. Pujol. 1980. Cycle spermatogénétique continu chez des Batraciens tropicaux. Bull. Soc. Zool. Fr. 105: 232-233.

Delsol, M., J. Flatin, M. Gueydan-Baconnier, F. Neyrand De Leffemberg \& P. Pujol. 1981. Action des facteurs externes sur les cycles de reproduction chez les Batraciens. Bull. Soc. Zool. Fr. 106: $419-431$.

Duellman, W.E. \& L. Trueb. 1986. Biology of Amphibians. Mc Graw Hill Book Company, New York.

EXBRAYAT, J.M. 1983. Premières observations sur le cycle annuel de l'ovaire de Typhlonectes compressicaudus (Duméril et Bibron, 1841), Batracien Apode vivipare. C. R. Séanc. Acad. Sci., Paris. 296: 493-498.

ExBRaYat, J.M. 1985. Cycle des canaux de Müller chez le mâle adulte de Typhlonectes compressicaudus (Duméril \& Bibron, 1841), Amphibien Apode. C. R. Séanc. Acad. Sci., Paris. 301: 507-512.

EXвRAYAT, J.M. 1986. Quelques aspects de la biologie de la reproduction chez Typhlonectes compressicaudus (Duméril et Bibron, 1841), Amphibien Apode. Unpublished D.Sci. thesis, Univ. Paris VI, France.

EXBRAYAT, J.M. 1988a. Croissance et cycle des voies génitales femelles chez Typhlonectes compressicaudus (Duméril et Bibron, 1841), Amphibien Apode vivipare. Amphibia Reptilia. 9: 117-137.

EXBRAYAT, J.M. 1988b. Variations pondérales des organes de réserve (corps adipeux et foie) chez Typhlonectes compressicaudus (Duméril \& Bibron, 1841) Amphibien Apode vivipare. Ann. Sci. Nat. Zool. $13^{\text {e }}$ sér. 9: 45-53.

Exbrayat, J.M. 2000. Les Gymnophiones, ces curieux Amphibiens. Boubée, Paris.

Exbrayat, J.M. 2001. Genome Visualization by Classic Methods in Light Microscopy. CRC Press, Boca Raton, London, New York.

ExBRayat, J.M. 2006a. Endocrinology of Reproduction in Gymnophiona. Pp. 183-229. In J.M. Exbrayat (Ed.) Reproductive Biology and Phylogeny of Gymnophiona Caecilians). Series edited by B.G.M. Jamieson, Vol. 5. Science Publishers, Enfield, Jersey, Plymouth.

Exbrayat, J.M. 2006b. Oogenesis and folliculogenesis. Pp. 275-290. In J.M. Exbrayat (Ed.) Reproductive Biology and Phylogeny of Gymnophiona (Caecilians). Series edited by B.G.M. Jamieson, Vol. 5. Science Publishers, Enfield, Jersey, Plymouth.

Exbrayat, J.M. \& G. Collenot. 1983. Quelques aspects de l'évolution de l'ovaire de Typhlonectes compressicaudus (Duméril et Bibron, 1841), Batracien Apode Vivipare. Etude quantitative et histochimique des corps jaunes. Rep. Nutr. Dév. 23: 889-989.

Exbrayat, J.M. \& M. Delsol. 1988. Oviparité et développement intrautérin chez les Gymnophiones. Bull. Soc. Herp. Fr. 45: 27-36.

Exbrayat, J.-M. \& J. Estabel. 2006. Anatomy with particular reference to the reproductive system. Pp. 79-155. In J.M. EXBRAYAT (Ed.) Reproductive Biology and Phylogeny of Gymnophiona Caecilians). Series edited by B.G.M. Jamieson, Vol. 5. Science Publishers, Enfield, Jersey, Plymouth.

Exbrayat, J.M. \& J. Flatin. 1985. Les cycles de reproduction chez les Amphibiens Apodes. Influence des variations saisonnières. Bull. Soc. Zool. Fr. 110: 301-305.

Exbrayat, J.M., P. Pujol \& B. LeClercQ. 1998. Quelques aspects des cycles sexuels et nycthéméraux chez les amphibiens. Bull. Soc. Zool. Fr. 123: 113-124.

Fiтch, H.S. 1970. Reproductive cycles of lizards and snakes. Misc. Publ. Mus. Natur. Hist. Univ. Kansas. 52: 1-247.

FiтcH, H.S. 1982. Resources of a snake community in prairie-woodland habitat of northeastern Kansas. Pp. 83-97. In N.J. ScotT JR (Ed.) Herpetological Communities: A Symposium of the Society for the Study of Amphibians and Reptiles and the Herpetologists' League, August 1977, U.S. Fish and Wildlife Service, Wildlife Research Report 13.

Fox, E.M., J. ANDRADE \& M.A. SHUPNIK. 2009. Novel actions of estrogen to promote proliferation: integration of cytoplasmic and nuclear pathways. Steroids 74: 622-627.

Gomes, A.D., C.A.A. Navas, C. Jared, M.M. Antoniazzi, N.R. Ceballos \& R.G. Moreira. 2013. Metabolic and endocrine changes during the reproductive cycle of dermatophagic caecilians in captivity. Zool. 116(5): 277-285. 
Gueydan-Baconnier, M. 1980. Le cycle sexuel chez les mâles et les femelles de Phrynobatrachus calcaratus (Peters, 1863) Batracien Anoure tropical. Unpublished Ph.D. thesis, Univ. Paris VI, France.

Gueydan-Baconnier, M., F. Neyrand De Leffemberg \& P. Pujol. 1984a. Comparaison de la vitesse spermatogénétique entre trois Batraciens tropicaux. Bull. Soc. Herp. Fr. 29: 69-70.

Gueydan-Baconnier, M., F. Neyrand De Leffemberg \& P. Pujol. 1984b. Etude comparative du dynamisme de la spermatogenèse chez trois Batraciens tropicaux par autoradiographie. Ann. Sci. Nat. Zool. 13e ser. 6: 191-196.

Huang, W.S., L. Jun-Yi \& J. Yuh-Lin Yu. 1996. The male reproductive cycle of the toad Bufo bankorensis. Taiwan Zool. St. 35: 128-137.

Huang, W.S., L. Jun-Yi \& J. Yuh-Lin Yu. 1997. Male reproductive cycle of the toad Bufo melanostictus. Taiwan Zool. Sci. 14: 497-503.

Hunter, M.G. \& D.T. Armstrong. 1987. Oestrogens inhibit steroid production by dispersed porcine thecal cells. Mol. Cell. Endocr. 50: 165-170.

JARED, C., C.A. NaVAS \& R.C. Toledo. 1999. An appreciation of the physiology and morphology of the Caecilians (Amphibia: Gymnophiona). Comp. Bioch. Physiol. A. 123: 313-328.

Kisserli, O. \& J.M. Exbrayat. 2006. Premières données sur le cycle de reproduction des mâles de Bufo mauritanicus (Schlegel, 1841) dans la zone humide de Beni-Belaid (Jijel, Algérie). Bull. Soc. Herp. Fr. 120: 5-13.

Kisserli, O. \& J.M. EXBRAYAT. 2013. Histologie et immunohistochimie des organes de reproduction de Bufo mauritanicus Schlegel, 1841. Bull. Soc. Herp. Fr. 145-146: 101-112.

Kisserli, O., S. Doumandj \& J.M. Exbrayat. 2011. Reproductive cycles in Bufo mauritanicus (Schlegel, 1841) of wet area of Beni-Belaïd (Jijel, Algeria). Bas. Appl. Herp. 25: 65-71.

Kumar, S., M. SARAdhi, N.K. Chaturvedi \& R.K. Tyagi. 2006. Intracellular localization and nucleocytoplasmic trafficking of steroid receptors: an overview. Mol. Cell. Endocr. 246: 147-156.

Kupfer, A., J. Nabhitabjata \& W. Himstedt. 2004. Reproductive ecology of female caecilian amphibians (genus Ichthyophis): a baseline study. Biol. J. Linn. Soc. 83: 207-217.

Kupfer, A., A. Kramer, W. Himstedt \& H. Greven. 2006. Copulation and egg retention in an oviparous Caecilian (Amphibia: Gymnophiona). Zool. Anz. 244: 223-228.

Lioutas, C., A. Einspanier, B. KascheiKe, N. Walther \& R. Ivell. 1997. An autocrine progesterone positive feedback loop mediates oxytocin upregulation in bovine granulosa cells during luteinization. Endocrinol. 138: 5059-5062.

Malonza, P.K., S.L. Lötters \& G.J. Measey. 2010. The montane forest associated amphibian species of the Taita Hills, Kenya. J. East Afr. Natur. Hist. 99: 47-63.

Malonza, P.K. \& G.J. Measey. 2005. Life history of an African caecilian: Boulengerula taitanus Loveridge 1935 (Amphibia Gymnophiona Caeciilidae). Trop. Zool. 18: 49-66.

Masood-Parveez, U. 1987. Some aspects of the reproduction in the female apodan Amphibian Ichthyophis. Unpublished Ph.D. thesis, Karnatak Univ., Dharwad, India.

Masood-ParveEz, U. \& V.B. NAdKARNI. 1993a. The ovarian cycle in an oviparous gymnophionan amphibian, Ichthyophis beddomei (Peters). J. Herp. 27: 59-63.

Masood-Parveez, U. \& V.B. NadKarni. 1993b. Morphological, histological and histochemical studies on the ovary of an oviparous Caecilian, Ichthyophis beddomei (Peters). J. Herp. 27: 63-69.

MEASEY, G.J. \& S. BAROT. 2006. Evidence of seasonal migration in a tropical subterranean vertebrate. J. Zool. 269: 29-37.

Measey, G.J., M. Smita, R.S. Beyo \& O.V. Oommen. 2008. Year-round spermatogenic activity in an oviparous subterranean caecilian, Boulengerula taitanus Loveridge 1935 (Amphibia Gymnophiona Caeciliidae). Trop. Zool. 21: 109-122.

Measey, G.J., P.K. Malonza \& V. Muchai. 2009. Amphibians of the Taita Hills/Amfibia wa milima ya Taita. Biodiv. Ser. 12. South African National Biodiversity Institute, Pretoria.

Nussbaum, R.A. \& H. Hinkel. 1994. Revision of East African caecilians of the genera Afrocaecilia Taylor and Boulengerula Tornier (Amphibia, Gymnophiona, Caecilidae). Copeia. 1994: 750-760.

Pelletier, G. 2000. Localization of androgen and estrogen receptors in rat and primate tissues. Hist. Histopathol. 15: 1261-1270.

Pelletier, G., C. Labrie \& F. Labrie. 2000. Localization of oestrogen receptor $\alpha$, oestrogen receptor $\beta$ and androgen receptors in the rat reproductive organs. J. Endocr. 165: 395-370.

Pujol, P. 1985. Quelques aspects de la reproduction du crapaud Bufo regularis Reuss, 1834. Unpubl. Diploma, EPHE, Lyon. 
Pujol, P. \& J.M. Exbrayat. 1996. Variation du tissu interstitiel du testicule et de l'hypophyse chez Bufo regularis mâle au cours du cycle sexuel. Bull. Soc. Herp. Fr. 8: 27-37.

Pujol, P. \& J.M. Exbrayat. 2000. Mise en évidence de l'homogénéité des testicules multilobés de deux Amphibiens par des méthodes morphométriques. Bull. Soc. Herp. Fr. 95: 43-56.

Pujol, P. \& J.M. Exbrayat. 2002. Quelques aspects de la biologie de la reproduction et des cycles sexuels chez Bufo regularis Reuss (1834) Amphibien Anoure. Bull. mens. Soc. Linn. Lyon. 71: $12-52$.

Raquet, M., G.J. Measey \& J.M. Exbrayat. 2007. Premières observations histologiques de l'ovaire de Boulengerula taitanus, Loveridge, 1935, Amphibien Gymnophione. Rev. Fr. Histotechn. 19: 9-15.

SARASIN, R. \& F. SARASIN 1887-1890. Zur Entwicklungeschichte und Anatomie der ceylonesishen Blindwühle Ichthyophis glutinosus L. In Ergebnisse naturwissenwchaftlicher Forschungen auf Ceylon. C.W. Kreidel's Verlag, Wiesbaden.

Seshachar, B.R. 1943. The spermatogenesis of Ichthyophis glutinosus (Linn.), III. Spermateleosis. Proc. Nat. Inst. Sci. India. 9: 271-285.

Seshachar, B.R., T.A. Balakrishna, K. Shakuntala \& K.R. Gundappa. 1982. Some unique features of egg laying and reproduction in Ichthyophis malabarensis (Taylor) (Apoda: Amphibia). Current Sci. 51: 32-34.

Smita, M., G.M. Jancy, M.A. Akbarsha, O.V. Oommen \& J.M. Exbrayat. 2006. Caecilian spermatogenesis. Pp. 231-274. In Exbrayat, J.M. (Ed.) Reproductive Biology and Phylogeny of Gymnophiona (Caecilians). Series edited by B.G.M. Jamieson, Vol. 5. Science Publishers, Enfield, Jersey, Plymouth.

TAYLOR, E.H. 1968. The Caecilians of the World. A taxonomic review. Univ. Kansas Press. Lawrence.

TonutTi, E. 1931. Beitrag zur Kenntnis des Gymnophionen. XV. Das Genital-system. Morph. Jahb. 68: $151-292$.

WAKE, M.H. 1968. Evolutionary morphology of the Caecilian urogenital system. Part I: the gonads and fat bodies. J. Morph. 126: 291-332.

WAKE, M.H. 1977. The reproductive biology of Caecilians. An evolutionary perspective. Pp. 73-100. In D.H. TAYLOR \& S.I. GutTMAN (Eds) The Reproductive Biology of Amphibians. Springer Verlag. Miami Univ., Oxford, Ohio.

WAKE, M.H. 1980. Reproduction, growth and population structure of the Central American Caecilian Dermophis mexicanus. Herpetologica. 36: 244-256.

WaKe, M.H. 1983. Gymnopis multiplicata, Dermophis mexicanus, and Dermophis parviceps (soldas, suelda con suelda, dos cabezas, caecilians). Pp. 400-401. In D. H. JANZEN (Ed.) Costa Rican Natural History. Univ. Chicago Press, Chicago, IL.

WAKE, M.H. 1995. The spermatogenic cycle of Dermophis mexicanus (Amphibia: Gymnophiona). J. Herp. 29: 119-122.

WAKE, M.H. \& R. DiCKIE. 1998. Oviduct structure and function and reproductive modes in Amphibians. J. Exp. Zool. 282: 477-506.

WhitTIER, J.M. \& D. CREWs. 1987. Seasonal reproduction: Patterns and control. Pp. 385-409. In D.O. Norris \& R.E.E. Jones (Eds) Hormone and Reproduction in Fishes, Amphibians and Reptiles. Springer/Plenum Press, New York.

Zhao, C., K. Dahlman-Wright \& J.Å. Gustafsson. 2008. Estrogen receptor $\beta$ : an overview and update. Nucl. recept. signal. 6:e03.

Zug, G.R. 1993. Herpetology: An Introductory Biology of Amphibians and Reptiles. Academic Press, San Diego, CA.

Received: 29 May 2015; Final acceptance: 1 October 2015 